\section{Phenological characteristics and yield potential of some late-ripening peach hybrids}

\author{
Aleksandar Radović ${ }^{1 *}$, Vera Rakonjac ${ }^{2}$, Grujica Vico ${ }^{3}$, Boban \\ Đorđević ${ }^{2}$, Dejan Đurović2 , Ivana Bakić ${ }^{4}$ and Dragan Nikolić ${ }^{2}$
}

\begin{abstract}
Phenological characteristics and yield potential in eight promising peach hybrids from selection based on fruit quality were studied in this paper. The hybrids flowered from late March to mid-April, and fruit ripened from late August to late September. The FS3, FS4, and FS7 hybrids had the highest density of flower buds. The initial fruit set was quite high (73.9\%) and the final fruit set was much lower (32.2\%). Fruit weight ranged from $129.8 \mathrm{~g}$ (FS4 hybrid) to $178.1 \mathrm{~g}$ (FS7 hybrid). The FS3 and FS7 hybrids had the highest yield per $1 \mathrm{~m}$ of shoot length $(3.5 \mathrm{~kg})$, and the FS2 hybrid had the highest yield per tree (25.3 $\mathrm{kg}$ ) and the highest yield efficiency $\left(0.30 \mathrm{~kg} \mathrm{~cm}^{-2}\right)$. The FS2, FS3, and FS7 hybrids stood out based on yield potential. They are good candidates for release as new high-yielding peach cultivars or for use in further breeding efforts.
\end{abstract}

Keywords: Prunus persica, phenology, density of flower buds, fruit set, yield.

\section{INTRODUCTION}

Peach is a fruit species characterized by a long season of consumption (June to October) in the Northern hemisphere. It is most commonly used for fresh consumption, although it is also appropriate for various types of processing into juice, compote, jam, etc. Peach is composed of a very dynamic range of varieties. New cultivars are quickly created and released for production, replacing old cultivars. So far, over 6.000 cultivars of different ripening time, size, appearance, and fruit taste have been created worldwide (Iglesias et al. 2010, Nikolić et al. 2016). Of particular interest are the cultivars that ripen outside the main season, as their fruit attains a higher price on the market (Raseira et al. 2018). Most peach cultivars have been created by planned hybridization, although other methods are used, such as inbreeding, clonal selection, and induced mutations, as well as new biotechnology methods (Nikolić et al. 2009). Currently, the main goal in peach breeding is creating cultivars that are adapted to different environmental conditions, resistant to diseases, and high yielding, as well as the creation of cultivars with prolonged ripening time (from very early to very late) and good quality, large, firm, and attractive fruit suitable for storage and transport (Cantín et al. 2010, Batlle et al. 2012, Bassi and Foschi 2013, Iglesias 2013). One of the very important goals of peach breeding is the creation of low-chill cultivars (Corrêa et al. 2019). Also, some breeding programs are aimed at creating rootstocks for peach of high uniformity, adapted to the growing region and with good interaction with cultivars (Oliveira et al. 2018). Work on the creation of new peach cultivars is most intense in the USA, Italy, France, and China (Nikolić and Fotirić-Akšić 2013). Eleven (11) peach cultivars have already been created in Serbia.
Crop Breeding and Applied Biotechnology 20(4): e33102045, 2020 Brazilian Society of Plant Breeding. Printed in Brazil http://dx.doi.org/10.1590/198470332020v20n4a58
E-mail: radovicaleksandar@yahoo author: (D) ORCID: 0000-0003-3059-8157

Received: 06 May 2020 Accepted: 05 July 2020 Published: 15 October 2020

${ }^{1}$ University of Niš, Faculty of Agriculture in Kruševac, Kosančićeva, 37.000, Kruševac, Serbia

${ }^{2}$ University of Belgrade, Faculty of Agriculture, Nemanjina, 11.080, Belgrade - Zemun, Serbia

${ }^{3}$ University of East Sarajevo, Faculty of Agriculture, Vuka Karadžića, 71.123, East Sarajevo, Bosnia and Herzegovina ${ }^{4}$ Institute for Science Application in Agriculture, Blvd. despota Stefana, 11.000, Belgrade, Serbia 
In Serbia, flowering of peach takes place from the end of March to the end of April, depending on the genotype and agroecological conditions (Glišić et al. 2008). It is one of the most important phenophases in the annual cycle, but also the most critical phase because peach yield largely depends on it. There is a high correlation between the flowering time and the yield components of peach (Rakonjac 2005). Knowing the flowering time can thus affect the selection of individual genotypes for growing in certain localities.

There are several groups of peach cultivars, which are divided into very early, early, early-medium, late-medium, late, and very late cultivars according to time of ripening. Most peach cultivars are characterized by early-medium and latemedium ripening, with very few cultivars of early and late ripening time. It is known that cultivars that are characterized by very early and very late ripening times achieve significantly higher prices on the market than cultivars that ripen in the main peach season in July and August. However, these cultivars generally have poorer fruit quality than that of the early-medium and late-medium ripening cultivars. Therefore, at the Faculty of Agriculture of the University of Belgrade, in the last two decades, a peach breeding program has been initiated with the aim of creating late-ripening cultivars which have large, attractive, and quality fruit.

Recommendation of genotypes for growing must take into account not only the quality and market characteristics of the fruit, but also yield. Peach yield is a complex trait that depends on numerous factors, primarily genetic but also environmental. Genetic factors of yield are the length, type, and number of fruiting branches per tree, number of flower buds per node and shoot, density of internodes, abundance of flowering, degree of fruit set, fruit size, etc. (Okie and Werner 1996, Radović et al. 2015). Among the environmental factors, climate factors, especially air temperature (e.g, the occurrence of severe winter and late spring frosts), have the biggest impact on yield (Milatović et al. 2010). Sanzol and Herrero (2001) state that the yield of fruit trees varies from year to year and is largely dependent on the weather during flowering, which affects pollination, pollen tube growth, and ovule longevity.

In Serbia, in many localities where peach is grown, flower buds often freeze due to low winter temperatures; flowers and young fruit may also freeze due to late spring frosts. Damage is particularly pronounced in genotypes that have lower yield potential, that is, fewer flower buds per node and shoot. Depending on the year, locality, and genotype, winter frost damage ranges from 10-100\% (Glišić et al. 2005), and late spring frost damage from 30-100\% (Zec et al. 2012). Therefore, it is very important to grow cultivars that have higher yield potential in localities where flower buds freeze so that satisfactory yields can be achieved.

The aim of this paper was to investigate the phenological characteristics and yield potential of eight promising peach hybrids compared to the Summerset cultivar. These hybrids could be significant for releases for production or for further breeding efforts.

\section{MATERIAL AND METHODS}

Eight promising peach hybrids obtained from crossing Flaminia $\times$ Summerset in the "Radmilovac" experimental field of the Faculty of Agriculture of the University of Belgrade were used as material for investigation in this paper. Selection of hybrids was based on late ripening time and fruit quality (Table 1). The hybrids are codified as FS1, FS2,

Table 1. Fruit quality of the peach hybrids and standard cultivar investigated

\begin{tabular}{|c|c|c|c|c|c|c|c|c|}
\hline Genotype & $\begin{array}{l}\text { Fruit } \\
\text { shape }\end{array}$ & $\begin{array}{l}\text { Fruit Ground } \\
\text { color }\end{array}$ & $\begin{array}{l}\text { Fruit over } \\
\text { color }(\%)\end{array}$ & $\begin{array}{c}\text { Soluble } \\
\text { solids } \\
(\%)\end{array}$ & $\begin{array}{c}\text { Total } \\
\text { acids } \\
(\%)\end{array}$ & $\begin{array}{c}\text { Soluble } \\
\text { solids/ } \\
\text { Total acids }\end{array}$ & $\begin{array}{l}\text { Balance acidity/ } \\
\text { sweetness of flesh }\end{array}$ & Flesh firmness \\
\hline FS1 & Round & Cream & 20 & 16.30 & 0.63 & 25.87 & Balanced & Firm \\
\hline FS2 & Round & Cream & 40 & 16.85 & 0.79 & 21.33 & Balanced & Firm \\
\hline FS3 & Round & Yellow & 90 & 13.25 & 0.50 & 26.50 & Balanced & Firm \\
\hline FS4 & Ovate & Orange yellow & 50 & 18.00 & 0.51 & 35.29 & Sweet & Firm \\
\hline FS5 & Round & Yellow & 75 & 13.15 & 0.45 & 29.22 & Sweet & Medium \\
\hline FS6 & Round & Yellow & 30 & 16.05 & 0.64 & 25.08 & Balanced & Medium \\
\hline FS7 & Round & Orange yellow & 90 & 13.30 & 0.54 & 24.63 & Balanced & Firm \\
\hline FS8 & Round & Orange yellow & 50 & 15.60 & 0.70 & 22.29 & Balanced & Medium \\
\hline Summerset & Round & Cream & 20 & 14.80 & 0.74 & 20.00 & Balanced & Firm \\
\hline
\end{tabular}


FS3, FS4, FS5, FS6, FS7, and FS8. The Summerset cultivar was used as a standard for comparison. The appearance of fruit from the promising peach hybrids and the standard cultivar are shown in Figure 1. The orchard was planted in 2006. A 'Fusetto' training system was used, and tree spacing was $4.5 \times 2.0 \mathrm{~m}$ (1111 trees ha $\left.{ }^{-1}\right)$. Vineyard peach was the rootstock. Phenological characteristics and yield potential were studied in the selected hybrids and the standard cultivar over a two-year period (2015-2016).

The phenological traits monitored were flowering and fruit ripening. The flowering phenophase was determined according to the recommendations of the International Working Group on Pollination (Wertheim 1996). The duration of flowering is the number of days from the start to the end of flowering, and the abundance of flowering is on a scale of 0-5: no flowering (0), very poor (1), poor (2), good (3), very good (4), and excellent (5). The starting date of harvest was the beginning of fruit ripening.

For vigor parameters, the length and diameter of 1-year-old shoots, length of internodes, and trunk cross-sectional area were examined. Trunk cross-sectional area $\left(\mathrm{cm}^{2}\right)$ was calculated based on the circumference of the trunk, which was measured at a height of $20 \mathrm{~cm}$ above the graft union.

The yield-potential parameters examined included the number of flower and vegetative buds on 1-year-old shoots, the ratio of flower buds/vegetative buds, the number of flower buds per node and in the length of $1 \mathrm{~m}$ of 1-year-old shoots, fruit set, fruit weight, yield per $1 \mathrm{~m}$ of shoot length, yield per tree, and yield efficiency.

Based on open-pollination results, an initial fruit set ( 3 weeks after anthesis) and a final fruit set (just before harvest) were determined. These values are expressed in \%. Fruit weight was measured on a digital scale. Yield per $1 \mathrm{~m}$ of shoot length $(\mathrm{kg})$ was the product of the number of peaches per $1 \mathrm{~m}$ of shoot length by average fruit weight. Yield per tree was obtained by weighing the fruit harvested from each individual tree in $\mathrm{kg}$. Yield efficiency $\left(\mathrm{kg} \mathrm{cm}^{-2}\right)$ was determined by dividing the yield per tree by the cross-sectional area of the trunk.
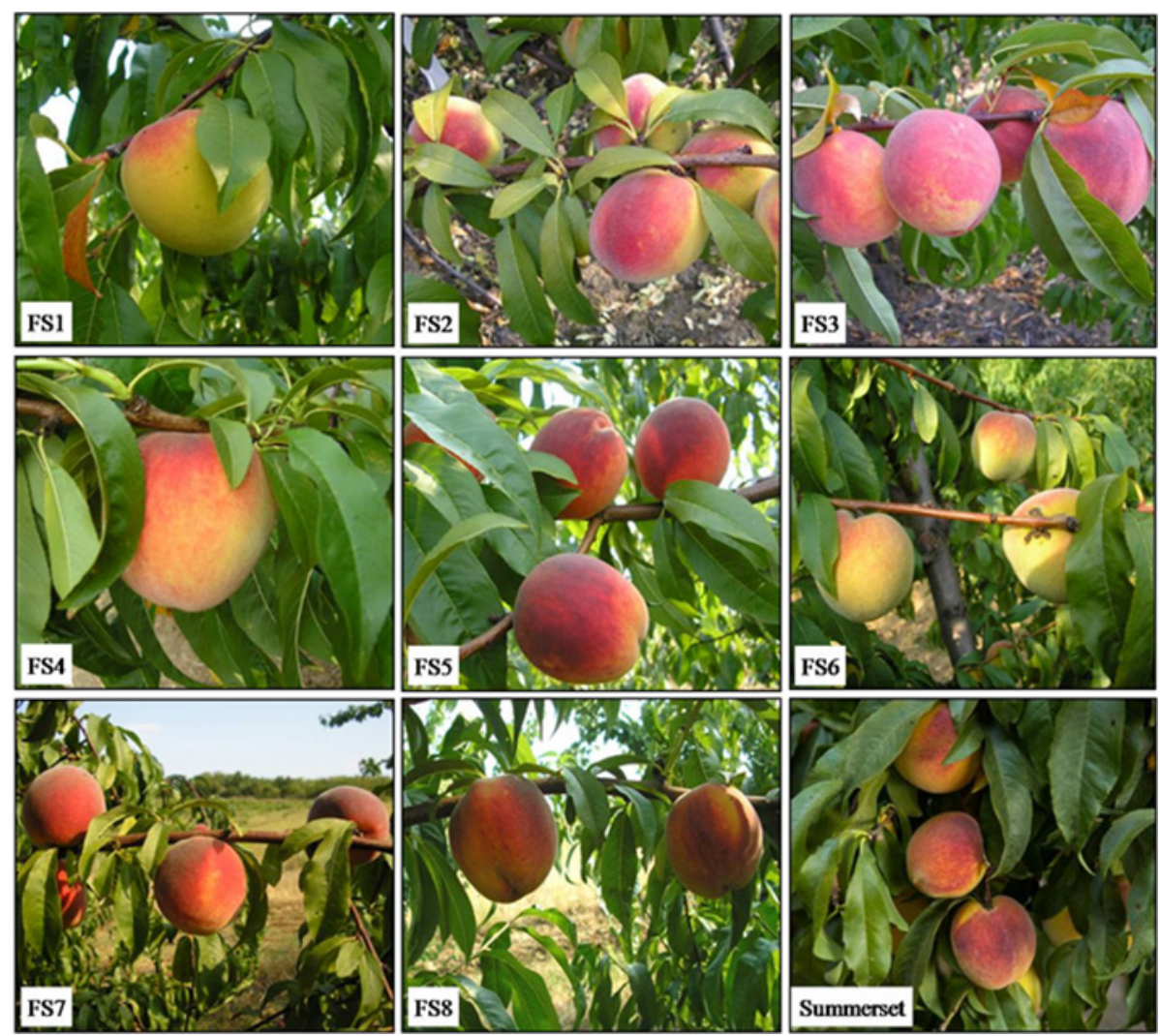

Figure 1. Fruit appearance of promising peach hybrids and standard cultivar. 
The results obtained were processed statistically using analysis of variance. Arcsine square root transformation was performed on the percentage data before the statistical analysis. Individual testing was carried out using Dunnett's test at $P \leq 0.05$. Coefficients of variation (CV) were calculated as relative indicators of variability. Data analysis was performed using the statistical software STATISTICA, Version 8 (StatSoft Inc., Tulsa, Oklahoma, USA).

\section{RESULTS AND DISCUSSION}

The peach hybrids in this study flowered between the end of March and the middle of April (Table 2). Flowering began first in the FS1 and FS6 hybrids (27 March), and the FS8 hybrid was the last to begin (31 March).

On average, full flowering was at three days after the start of flowering; it was earliest in the FS6 hybrid (29 March) and latest in the FS8 hybrid (03 April). The end of flowering was in accordance with the previous two sub-phases, occurring earliest in the FS6 hybrid (05 April) and latest in the FS8 hybrid (12 April). The flowering time of peach hybrids in our study is consistent with the results of Zec et al. (2009) for a similar locality. Flowering lasted an average of 11.1 days, and ranged from 9.0 days (FS6 hybrid) to 13.0 days (FS2 hybrid). Flowering in the standard Summerset cultivar lasted 10.5 days. The degree of fruit set and yield largely depend on the abundance of flowering, which is a genetic trait of the species and, specifically, of the cultivar. The Summerset cultivar had the worst score for flowering abundance (2.5) and the FS5 hybrid received the best (5.0).

Determining the harvest time of peach fruit is extremely important for producers, traders, and consumers. A large number of parameters should be taken into account in this determination: fruit size, reddish fruit skin, fruit firmness, and content of soluble solids, total acids, and chlorophyll in the fruit (Sortino et al. 2015). Peach ripening time is a highly heritable trait (De Souza et al. 1998a). The hybrids tested in our study were characterized by late ripening time (from the end of August to the end of September). Ripening time was earliest in the FS8 hybrid (29 August) and latest in the FS6 hybrid (27 September). Fruit from the standard cultivar ripened on 24 September. The FS2 and FS6 hybrids had a later ripening time than standard cultivar. Fruit of the Summerset cultivar ripened slightly earlier in this study in Radmilovac than under the conditions of Čačak shown in the results of Ogašanović et al. (2002). This can be explained by differences in the ecological conditions of these two localities. In the phenological phases of peach mentioned, the highest variability was found for abundance of flowering ( $C V=23.1 \%)$ and fruit ripening time $(C V=22.5 \%)$ and the lowest for the start of flowering ( $C V=4.1 \%)$.

Properties of 1-year-old shoots are a very important parameter in the evaluation of peach vigor and yield potential. One-year-old shoots are mainly responsible for peach yield, and they provide fruit of the highest quality (Radović et al. 2015). The length of one-year-old shoots varied slightly $(C V=9.2 \%)$ and did not differ significantly between hybrids and the standard Summerset cultivar $(42.5 \mathrm{~cm}$ ) (Table 3). The FS8 hybrid had the longest one-year-old shoots $(51.2 \mathrm{~cm})$ and the FS3 hybrid had the shortest $(36.9 \mathrm{~cm})$. The length of the one-year-old shoots in our study varied more than the length determined by Okie and Werner (1996) for some peach cultivars in the United States, lengths which ranged from 45.2 to $56.1 \mathrm{~cm}$. The resulting differences may be due to a number of factors, such as genotype, agroecological conditions, and crop management practices.

Table 2. Phenological characteristics of the peach hybrids and standard cultivar investigated (average 2015-2016)

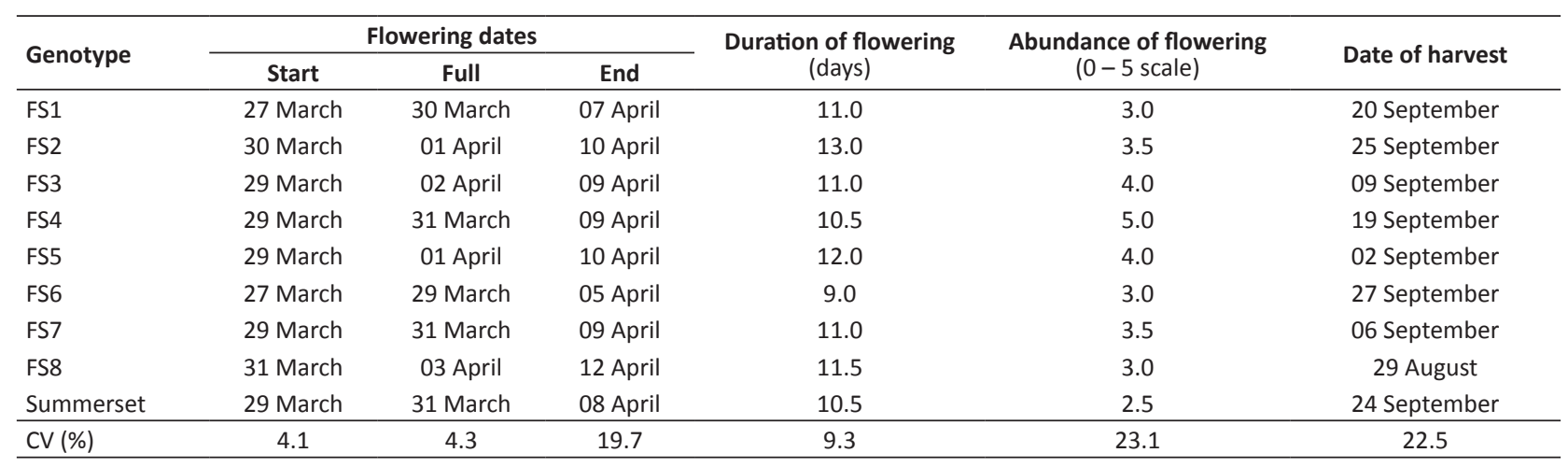


Phenological characteristics and yield potential of some late-ripening peach hybrids

Table 3. Vigor parameters and number of flower and vegetative buds on 1-year-old shoots of peach the hybrids and standard cultivar investigated (average 2015-2016)

\begin{tabular}{|c|c|c|c|c|c|c|c|c|c|}
\hline \multirow[b]{2}{*}{ Genotype } & \multicolumn{3}{|c|}{ One-year-old shoots } & \multirow{2}{*}{$\begin{array}{l}\text { Trunk cross- } \\
\text { sectional area } \\
\left(\mathrm{cm}^{2}\right)\end{array}$} & \multicolumn{2}{|c|}{ Nr. of buds per shoot } & \multirow{2}{*}{$\begin{array}{l}\text { Ratio of flower buds/ } \\
\text { vegetative buds }\end{array}$} & \multicolumn{2}{|c|}{ Nr. of flower buds } \\
\hline & $\begin{array}{c}\text { Length } \\
(\mathrm{cm})\end{array}$ & $\begin{array}{c}\text { Diameter } \\
(\mathrm{mm})\end{array}$ & $\begin{array}{l}\text { Length of } \\
\text { internodes } \\
(\mathrm{cm})\end{array}$ & & Flower & Vegetative & & Per node & $\begin{array}{c}\text { Per } 1 \mathrm{~m} \\
\text { length }\end{array}$ \\
\hline FS1 & $39.6 \mathrm{a}$ & $6.5 \mathrm{a}$ & $1.9 \mathrm{a}$ & $81.6 \mathrm{~b}$ & $18.7 \mathrm{a}$ & $20.3 \mathrm{a}$ & $0.94 \mathrm{a}$ & $0.90 \mathrm{a}$ & $49.4 \mathrm{a}$ \\
\hline FS2 & $41.1 \mathrm{a}$ & $6.6 \mathrm{a}$ & $1.8 \mathrm{a}$ & $85.6 b$ & $21.3 \mathrm{a}$ & $22.7 \mathrm{a}$ & $0.94 \mathrm{a}$ & $0.94 \mathrm{a}$ & $52.5 \mathrm{a}$ \\
\hline FS3 & 36.9 a & $4.0 \mathrm{~b}$ & $2.2 \mathrm{a}$ & $102.3 \mathrm{a}$ & $24.0 \mathrm{a}$ & $17.7 \mathrm{a}$ & $1.33 \mathrm{~b}$ & $1.33 \mathrm{~b}$ & $65.6 \mathrm{a}$ \\
\hline FS4 & $42.1 \mathrm{a}$ & $5.9 \mathrm{a}$ & $1.9 \mathrm{a}$ & $95.3 \mathrm{a}$ & $27.5 \mathrm{~b}$ & $22.7 \mathrm{a}$ & $1.22 \mathrm{a}$ & $1.20 \mathrm{~b}$ & $68.7 \mathrm{a}$ \\
\hline FS7 & $39.3 \mathrm{a}$ & $6.4 \mathrm{a}$ & $1.8 \mathrm{a}$ & $120.2 \mathrm{a}$ & $22.5 \mathrm{a}$ & $21.2 \mathrm{a}$ & $1.07 \mathrm{a}$ & $1.03 \mathrm{a}$ & $60.0 \mathrm{a}$ \\
\hline FS8 & $51.2 \mathrm{a}$ & 7.9 a & $2.3 \mathrm{a}$ & $119.4 \mathrm{a}$ & $25.7 \mathrm{~b}$ & $22.5 \mathrm{a}$ & $1.14 \mathrm{a}$ & $1.13 \mathrm{a}$ & $54.3 \mathrm{a}$ \\
\hline Summerset & $42.5 \mathrm{a}$ & $7.0 \mathrm{a}$ & $2.2 \mathrm{a}$ & $115.2 \mathrm{a}$ & $16.0 \mathrm{a}$ & $20.0 \mathrm{a}$ & $0.81 \mathrm{a}$ & $0.77 \mathrm{a}$ & $38.1 \mathrm{a}$ \\
\hline CV (\%) & 9.2 & 16.4 & 9.5 & 26.9 & 15.1 & 7.3 & 14.1 & 15.2 & 16.0 \\
\hline
\end{tabular}

The averages followed by 'a' do not differ significantly, and the averages followed by ' $b$ ' differ significantly or very significantly from the standard according to Dunnett's test at $P \leq 0.05$.

In contrast to length, the diameter of the one-year-old shoots in our study varied significantly (CV $=16.4 \%)$, ranging from $4.0 \mathrm{~mm}$ (FS3 hybrid) to $7.9 \mathrm{~mm}$ (FS7 hybrid). The length of internodes is an important feature that can indicate the genotype yield potential and vigor. In our study, length of internodes internode length did not significantly deviate from the standard cultivar and ranged from $1.8 \mathrm{~cm}$ (FS2 and FS7 hybrids) to $2.3 \mathrm{~cm}$ (FS8 hybrid).

Trunk cross-sectional area indicates the vigor of hybrids. It depends not only on the genotype of the cultivar, but especially on the rootstock on which the cultivar is grafted (Remorini et al. 2015). The trunk cross-sectional area averaged $114.3 \mathrm{~cm}^{2}$ for all hybrids and the standard cultivar. It ranged from $81.6 \mathrm{~cm}^{2}$ (FS1 hybrid) to $192.0 \mathrm{~cm}^{2}$ (FS5 hybrid). This indicates that the FS1 hybrid had the lowest vigor and the FS5 hybrid the highest vigor. Trunk cross-sectional area of the Summerset cultivar was $115.2 \mathrm{~cm}^{2}$. The FS5 hybrid had significantly higher vigor and the FS1 and FS2 hybrids significantly lower vigor compared to Summerset. The coefficient of variation for this trait was $26.9 \%$.

The number of flower buds per shoot varied significantly among the hybrids studied. It was significantly higher in the FS4 (27.5) and FS8 (25.7) hybrids than in the standard Summerset cultivar, which had the lowest number of flower buds per shoot (16.0). This is in line with the results found by Milatović et al. (2017) for some peach cultivars in the Belgrade region. The number of vegetative buds per shoot in the hybrids tested did not differ significantly from the Summerset cultivar and ranged from 17.7 (FS3 hybrid) to 22.7 (FS2 and FS4 hybrids).

The ratio between the number of flowering and vegetative buds is a very important parameter to strike a balance between yield and fruit quality. This ratio was on average near, or slightly higher, in favor of flower buds. The highest ratio between the number of flowering and vegetative buds was found in the FS3 hybrid (1.33) and was significantly higher than in the Summerset cultivar, which had the lowest ratio (0.81). In most hybrids, the ratio between the number of flowering and vegetative buds was above 1, indicating that they have high yield potential.

In peach, the one-year-old shoots have flower and vegetative buds separated and together on the same node. The number of flower buds per node is a very significant parameter of peach yield, especially in areas where late spring frosts often occur. In such areas, a greater number of flower buds per node provide greater assurance of adequate yield (Byrne 1986). The largest number of flower buds per node in our study was found in hybrids FS3 (1.33) and FS4 (1.20). It was significantly higher in these two hybrids than in the standard Summerset cultivar, which had the smallest number of flower buds per node (0.77). The number of flower buds per node was consistent with the results of Milatović et al. (2017). Authors have characterized genotypes with more than 1.0 flower buds per node as potentially high yielding, and genotypes with fewer than 0.8 flower buds per node as potentially lower yielding. According to this division, most of the genotypes examined in our study can be considered potentially high yielding.

The number of flower buds per $1 \mathrm{~m}$ length is a significant indicator of flower bud density (Radović et al. 2015). Flower bud density is very significant for yield (Thurzó et al. 2006). It is moderately heritable and is recommended as the most 


\section{A Radović et al.}

Table 4. Fruit set, fruit weight, and yield of the peach hybrids and standard cultivar investigated (average, 2015-2016)

\begin{tabular}{|c|c|c|c|c|c|c|}
\hline Genotype & $\begin{array}{c}\text { Initial fruit set } \\
(\%)\end{array}$ & $\begin{array}{c}\text { Final fruit set } \\
(\%)\end{array}$ & $\begin{array}{l}\text { Fruit weight } \\
(\mathrm{g})\end{array}$ & $\begin{array}{l}\text { Yield per } 1 \mathrm{~m} \text { of shoot length } \\
(\mathrm{kg})\end{array}$ & $\begin{array}{c}\text { Yield per tree } \\
(\mathrm{kg})\end{array}$ & $\begin{array}{l}\text { Yield efficiency } \\
\left(\mathrm{kg} \mathrm{cm}^{-2}\right)\end{array}$ \\
\hline FS2 & $76.8 \mathrm{a}$ & $40.8 \mathrm{~b}$ & $173.4 \mathrm{a}$ & $3.1 \mathrm{a}$ & $25.3 \mathrm{~b}$ & $0.30 \mathrm{~b}$ \\
\hline FS4 & $84.1 b$ & $33.6 \mathrm{a}$ & $129.8 b$ & $2.9 \mathrm{a}$ & $17.4 \mathrm{a}$ & $0.18 a$ \\
\hline FS5 & $70.0 \mathrm{a}$ & $31.1 \mathrm{a}$ & $151.0 \mathrm{a}$ & $2.6 \mathrm{a}$ & $20.1 \mathrm{a}$ & $0.11 \mathrm{a}$ \\
\hline FS8 & $59.6 \mathrm{a}$ & $29.6 \mathrm{a}$ & 133.9 a & $2.2 \mathrm{a}$ & $16.4 \mathrm{a}$ & $0.14 a$ \\
\hline Summerset & $57.4 \mathrm{a}$ & $25.3 \mathrm{a}$ & $155.3 \mathrm{a}$ & $1.5 \mathrm{a}$ & $17.3 \mathrm{a}$ & $0.15 \mathrm{a}$ \\
\hline CV (\%) & 12.6 & 12.3 & 11.4 & 25.5 & 14.9 & 30.2 \\
\hline
\end{tabular}

The averages followed by 'a' do not differ significantly, and the averages followed by ' $b$ ' differ significantly or very significantly from the standard according to Dunnett's test for $P \leq 0.05$.

important parameter when selecting peaches for yield (De Souza et al. 1998b). In our study, the number of flower buds per $1 \mathrm{~m}$ length ranged from 38.1 in the Summerset cultivar to 65.6 in the FS3 hybrid and 68.7 in the FS4 hybrid. The number of flower buds per $1 \mathrm{~m}$ length was higher and less variable than the number found by Milatović et al. (2010) for some peach cultivars, in which the number of flowers per $1 \mathrm{~m}$ length ranged from 14.5 to 55.6. The genotype was most likely the cause of manifestation of these differences.

Fruit set is a very important trait that has a preponderant effect on peach yield. Peach cultivars that have a medium to high fruit set can achieve a yield of nearly $20 \mathrm{t} \mathrm{ha}^{-1}$ in an adult orchard (Raseira et al. 2020). The hybrids studied had a very high initial fruit set (Table 4). The highest initial fruit set was found in the FS4 hybrid (84.1\%). A high initial fruit set was also found in the FS6 (83.0\%) and FS3 (79.3\%) hybrids. These hybrids had a significantly higher initial fruit set than the Summerset cultivar, which had the lowest initial fruit set (57.4\%). In addition to the genotype, the fruit set in peach also varies depending on the environmental conditions at the flowering time (Santana et al. 2020).

In accordance with the lowest initial fruit set, the Summerset cultivar also had the lowest final fruit set (25.3). The FS2 hybrid had the highest final fruit set (40.8\%) and it was significantly higher than the final fruit set of the Summerset cultivar. The data for the initial and final fruit set of the Summerset cultivar are in accordance with the results of Milatović et al. (2010). The initial fruit set $(C V=12.6 \%)$ and final fruit set $(C V=2.3 \%)$ had fairly uniform variability.

Fruit weight is a very important trait that largely determines the market value of the fruit and the peach yield. Breeding in order to increase fruit weight has achieved better results in industrial than in fresh peach cultivars (Corrêa et al. 2019). This trait is highly correlated with fruit dimensions (Albuquerque et al. 2004) and carotenoid content in fruit (Matias et al. 2016). It ranged from $129.8 \mathrm{~g}$ (FS4 hybrid) to $178.1 \mathrm{~g}$ (FS7 hybrid) and was consistent with the results found by Raseira et al. (2020). Fruit weight was significantly higher in the FS7 hybrid and significantly lower in the FS4 and FS6 hybrids compared to the Summerset cultivar (155.3 g). The fruit weight of the Summerset cultivar was higher than the fruit weight determined by Ogašanović et al. (2002) under the conditions of western Serbia. This indicates that other factors besides the genotype (agroecological conditions and crop management technology) greatly affect fruit weight. This is confirmed by the results of a study by De Souza et al. (1998a), who found that fruit weight in peach was a moderately heritable trait under Texas conditions.

Yield per $1 \mathrm{~m}$ of shoot length was lowest for the Summerset cultivar $(1.5 \mathrm{~kg})$ and highest for the FS3 and FS7 hybrids (3.5 kg). These two hybrids had significantly higher yield per $1 \mathrm{~m}$ of shoot length than the Summerset cultivar. Yield per tree ranged from $16.4 \mathrm{~kg}$ (FS8 hybrid) to $25.3 \mathrm{~kg}$ (FS2 hybrid). The FS2 hybrid had a significantly higher yield per tree than the standard cultivar (17.3 kg). Yield per tree in our study was higher than the yield obtained by Zec et al. (2014) under a similar cultivation system for some cultivars of late-medium- and late-ripening peach in the Belgrade region. With these authors, yield per tree ranged from 11.6 to $17.9 \mathrm{~kg}$. These differences were largely a manifestation of the effect of genotype. Yield per tree depends on genotype and also varies significantly depending on tree spacing; yield per tree is higher with more widely dispersed plants than at high density; however, yield per hectare is higher with smaller tree 
spacing (Grossman and De Yong 1998, Caruso et al. 1999). Also, the yield per tree varies depending on environmental factors, primarily the occurrence of low temperatures during flowering and different rootstocks on which are grafted cultivars (Santana et al. 2020).

Yield efficiency is a significant indicator that integrates the yield and the vigor of genotypes. It is primarily conditioned by genotype and, unlike yield per tree, does not differ significantly from one training system to another (Caruso et al. 1999). Although the FS5 hybrid had high yield per tree, it had the lowest yield efficiency $\left(0.11 \mathrm{~kg} \mathrm{~cm}^{-2}\right)$ due to its high vigor. In contrast, due to its high yield per tree and low vigor, the FS2 hybrid had the highest yield efficiency $(0.30 \mathrm{~kg}$ $\mathrm{cm}^{-2}$ ). This indicates that this hybrid is suitable for growing in a dense planting system, in which it can achieve high yield. Yield efficiency had greater variability ( $C V=30.2 \%)$ than yield per $1 \mathrm{~m}$ of shoot length $(25.5 \%)$ and yield per tree $(14.9 \%)$.

\section{CONCLUSIONS}

Peach hybrids flower from late March to mid-April, and fruit ripens from late August to late September. The number of flower buds per shoot was significantly higher in the FS4 and FS8 hybrids and the number of flower buds per node significantly higher in the FS3 and FS4 hybrids than in the Summerset cultivar. The FS3, FS4, and FS8 hybrids had a significantly higher initial fruit set and the FS2 hybrid a significantly higher final fruit set than the standard cultivar. Fruit weight was significantly higher in the FS7 hybrid. Yield per $1 \mathrm{~m}$ of shoot length was significantly higher in the FS3 and FS7 hybrids and yield per tree and yield efficiency in the FS2 hybrid than in the Summerset cultivar.

Based on yield potential, the hybrids FS2, FS3, and FS7 stood out. They are good candidates for release as new highyielding peach cultivars, and for growing in areas where there is a risk of frost. They can also serve as valuable material for use in future breeding work.

\section{ACKNOWLEDGMENTS}

This study was supported by the Ministry of Education, Science and Technological Development of the Republic of Serbia through project TR 31063.

\section{REFERENCES}

Albuquerque AS, Bruckner CH, Cruz CD, Salomão, LCC and Neves JCL (2004) Repeatability and correlations among peach physical traits. Crop Breeding and Applied Biotechnology 4: 441-445.

Bassi D and Foschi S (2013) Trends in apricot and peach industries in Italy. In Milatović D (ed) Proceedings of the $4^{\text {th }}$ conference "Innovations in Fruit Growing - Improving peach and apricot production". University in Belgrade, Faculty of Agriculture, Belgrade, p. 49-73.

Batlle I, Fontich C, Lozano L, Iglesias I, Reig G, Alegre S, Echeverría G, de Herralde F, Clavería E, Dolcet-Sanjuan R, Carbó J, Bonany J, Maillard A and Maillard L (2012) The peach breeding programme IRTA-ASF: aiming for high fruit quality. Acta Horticulturae 940: 75-78.

Byrne DH (1986) Mechanisms of spring freeze injury avoidance in peach. HortScience 21: 1235-1236.

Cantín C, Gogorcena Y and Moreno MA (2010) Phenotypic diversity and relationships of fruit quality traits in peach and nectarine [Prunus persica (L.) Batsch] breeding progenies. Euphytica 171: 211-226.

Caruso T, Inglese P, Sottile F and Marra FP (1999) Effect of planting system on productivity, dry-matter partitioning and carbohydrate content in aboveground components of 'Flordaprince' peach trees. Journal of the American Society for Horticultural Science 124: 39-45.

Corrêa ER, Nardino M, Barros WS and Raseira MCB (2019) Genetic progress of the peach breeding program of Embrapa over 16 years. Crop Breeding and Applied Biotechnology 19: 319-328.

De Souza VAB, Byrne DH and Taylor JF (1998a) Heritability, genetic and phenotypic correlations, and predicted selection response quantitative traits in peach. II. An analysis of several fruit traits. Journal of the American Society for Horticultural Science 123: 604-611.

De Souza VAB, Byrne DH and Taylor JF (1998b) Heritability, genetic and phenotypic correlations, and predicted selection response of quantitative traits in peach I. An analysis of several reproductive traits. Journal of the American Society for Horticultural Science 123: 598-603.

Glišić I, Cerović R, Milošević T and Karaklajić-Stajić Ž (2008) Phenophase of flowering and pollen germination of some peach cultivars. Journal of Pomology 42: 97-102.

Glišić I, Mitrović M, Karaklajić Stajić Ž and Blagojević M (2005) Resistance of some peach cultivars and hybrids to lower temperatures in the area of Čačak. Proceedings of research papers Institute PKB Agroekonomik 11: 38-45.

Grossman YL and De Yong T (1998) Training and pruning system effects on vegetative growth potential, light interception and cropping efficiency in peach trees. Journal of the American Society for Horticultural Science 123: 1058-1064. 
Iglesias I (2013) Peach production in Spain: current situation and trends, from production to consumption. In Milatović D (ed) Proceedings of the $4^{\text {th }}$ conference "Innovations in Fruit Growing - Improving peach and apricot production". University in Belgrade, Faculty of Agriculture, Belgrade, p. 75-98.

Iglesias I, Reig G, Montserrat R, Carbó J and Bonany J (2010) Innovación varietal en nectarina y melocotón plano o paraguayo. Revista de Fruticultura: Especial melocotonero, nectarina y paraguayo 9: 4-17.

Matias RGP, Silva DFP, Miranda PMD, Oliveira JAA, Pimentel LD and Bruckner CH (2016) Relationship between fruit traits and contents of ascorbic acid and carotenoids in peach. Crop Breeding and Applied Biotechnology 16: 348-354.

Milatović D, Nikolić D and Đurović D (2010) Variability, heritability and correlations of some factors affecting productivity in peach. Horticultural Science (Prague) 37: 79-87.

Milatović D, Zec G, Đurović D and Boškov $Đ$ (2017) Characteristics of fruiting shoots of some peach and nectarine cultivars. Journal of Agricultural, Food and Environmental Sciences 71: 126-130.

Nikolić D and Fotirić-Akšić M (2013) Peach breeding in the world. In Milatović D (ed) Proceedings of the $4^{\text {th }}$ conference "Innovations in Fruit Growing - Improving Peach and Apricot Production". University in Belgrade, Faculty of Agriculture, Belgrade, p. 5-27.

Nikolić D, Ognjanov V, Korać N and Rakonjac V (2009) Objectives, methods and accomplishments in fruit and grape breeding. Journal of Pomology 43: 5-16.

Nikolić D, Radović A and Rakonjac V (2016) Fruit quality of promising peach hybrids. In Pospišil M and Vnučec I (eds) Proceeding of $51^{\text {st }}$ Croatian and $11^{\text {th }}$ International Symposium on Agriculture. University of Zagreb, Faculty of Agriculture, Opatija, p. 437-441.

Ogašanović D, Mitrović M and Plazinić R (2002) Biological-pomological properties of newly introduced peach cultivars. Journal of Yugoslav Pomology 36: 107-112.

Okie WR and Werner DJ (1996) Genetic influence on flower bud density in peach and nectarine exceeds that of environment. HortScience 31: 1010-1012.

Oliveira JAA, Bruckner CH, Silva DFP, Santos CEM, Penso GA and Aquino CF (2018) Estimation of genetic parameters and selection for rooting capacity in peach. Crop Breeding and Applied Biotechnology 18: 320-324.

Radović A, Nikolić D, Rakonjac V and Bakić I (2015) Characteristics of one-year-old shoots of peach hybrids from the crossing combination Flaminia $\times$ Hale Tardiva Spadoni. Journal of Agricultural Sciences (Belgrade) 60: 435-442.

Rakonjac V (2005) Correlative relation of yield and fruit quality with some phenological phases in peach. Genetika 37: 199-207.

Raseira MCB, Franzon RC, Pereira JFM, Scaranari C and Feldberg NP (2018) Peach cultivar BRS Citrino. Crop Breeding and Applied Biotechnology 18: 234-236.

Raseira MCB, Franzon RC, Feldberg NP, Scaranari C and Pereira JFM (2020) BRS Jaspe: a processing peach cultivar for low chill areas. Crop Breeding and Applied Biotechnology 20: e26652015.

Remorini D, Fei C, Loreti F and Massai R (2015) Observations on nine peach rootstocks grown in a replant soil. Acta Horticulturae 1084: 131-137.

Santana AS, Uberti A, Lovatto M, Prado J, Santos MV, Rocha JRASC, Mayer NA and Giacobbo CL (2020) Adaptability and stability of peach yield of cultivar BRS Libra grafted on different rootstocks in the subtropics. Crop Breeding and Applied Biotechnology 20: e314620218.

Sanzol J and Herrero M (2001) The "effective pollination period" in fruit trees. Scientia Horticulturae 90: 1-17.

Sortino G, Farina V, Liguori G and Gallotta A (2015) Prediction of harvest time in peach [Prunus persica (L.) batsch] fruit using the da-meter. Acta Horticulturae 1084: 771-776.

Thurzó S, Drén G, Dani M, Hlevnjak B, Hazic V, Szabó Z, Racskó J, Holb IJ and Nyéki J (2006) Fruit bearing shoot characteristics of apricot and sweet cherry cultivars in Hungary. International Journal of Horticultural Science 12: 107-110.

Wertheim SJ (1996) Methods for cross pollination and flowering assessment and their interpretation. Acta Horticulturae 423: 237241.

Zec G, Milatović D, Čolić S and Janković Z (2012) Effect of winter and spring frost on the freezing injury of peach and almond cultivars. Proceedings of research papers Institute PKB Agroekonomik 18: 61-67.

Zec G, Čolić S and Janković Z (2009) Pomological characteristics of late ripening nectarine cultivars. Journal of Pomology 43: 31-35.

Zec G, Čolić S, Milatović D, Vulić T, Đorđević B, Đurović D and Veličković M (2014) Influence of planting density on yield of peach and nectarine. In Kovačević D (ed) Proceeding of $\mathbf{5}^{\text {th }}$ International Scientific Agricultural Symposium "Agrosym". University of East Sarajevo, Faculty of Agriculture, Jahorina, p. 204-208.

(c) $\mathrm{EY}$ This is an Open Access article distributed under the terms of the Creative Commons Attribution License, which permits unrestricted use, distribution, and reproduction in any medium, provided the original work is properly cited. 